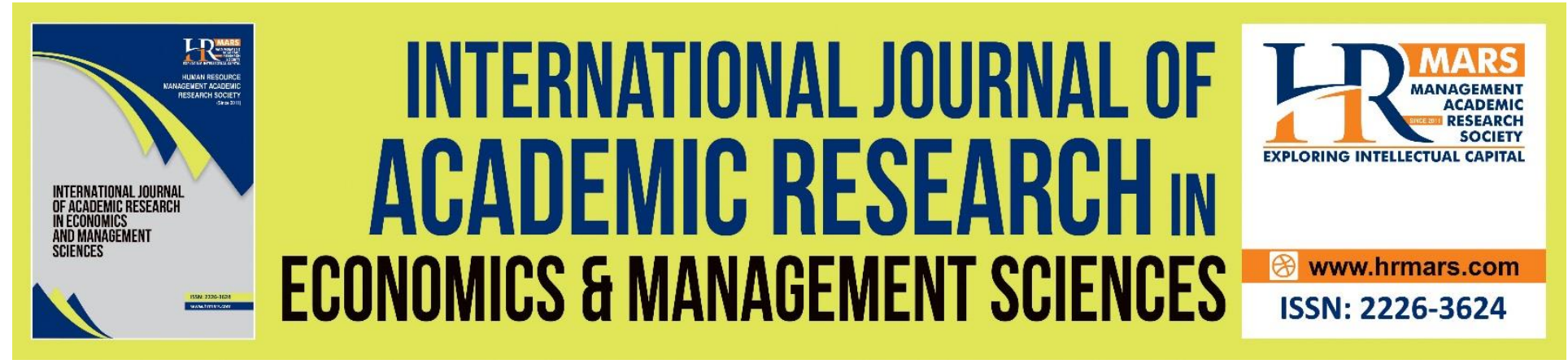

\title{
Intellectual Capital and Firm Performance: Evidence from Technology Sector in Malaysia
}

\section{Shaira Arwine Binti Shairi, Hapsah S. Mohammad, Jasman Tuyon}

To Link this Article: http://dx.doi.org/10.6007/IJAREMS/v10-i1/9834

DOI:10.6007/IJAREMS/v10-i1/9834

Received: 25 January 2021, Revised: 28 February 2021, Accepted: 16 March 2021

Published Online: 31 March 2021

In-Text Citation: (Shairi et al., 2021)

To Cite this Article: Shairi, S. A. B., Mohammad, H. S., \& Tuyon, J. (2021). Intellectual Capital and Firm Performance: Evidence from Technology Sector in Malaysia. International Journal of Academic Research in Economics and Managment and Sciences, 10(1), 244-258.

Copyright: (C) 2021 The Author(s)

Published by Human Resource Management Academic Research Society (www.hrmars.com)

This article is published under the Creative Commons Attribution (CC BY 4.0) license. Anyone may reproduce, distribute, translate and create derivative works of this article (for both commercial and non-commercial purposes), subject to full attribution to the original publication and authors. The full terms of this license may be seen

at: $\underline{\text { http://creativecommons.org/licences/by/4.0/legalcode }}$

Vol. 10, No. 1, 2021, Pg. 244 - 258

http://hrmars.com/index.php/pages/detail/IJAREMS

JOURNAL HOMEPAGE

Full Terms \& Conditions of access and use can be found at http://hrmars.com/index.php/pages/detail/publication-ethics 


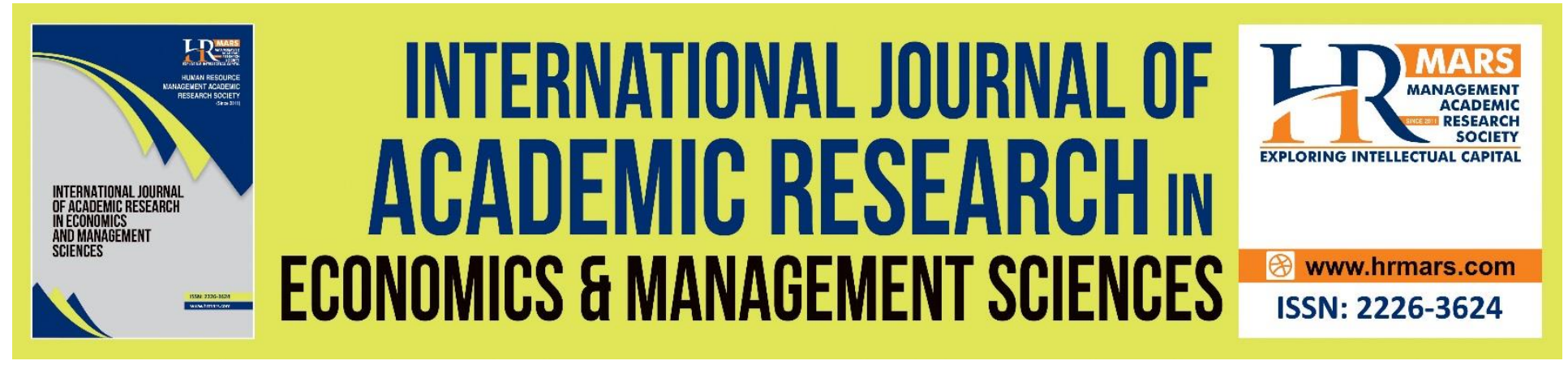

\title{
Intellectual Capital and Firm Performance: Evidence from Technology Sector in Malaysia
}

\author{
Shaira Arwine Binti Shairi \\ Faculty of Business and Management, Universiti Teknologi MARA (UiTM) Sabah Branch, Kota \\ Kinabalu Campus, 88997 Kota Kinabalu, Sabah, Malaysia \\ Hapsah S. Mohammad \\ Faculty of Accountancy, Universiti Teknologi MARA (UiTM) Sabah Branch, Kota Kinabalu \\ Campus, 88997 Kota Kinabalu, Sabah, Malaysia \\ Jasman Tuyon \\ Faculty of Business and Management, Universiti Teknologi MARA (UiTM) Sabah Branch, Kota \\ Kinabalu Campus, 88997 Kota Kinabalu, Sabah, Malaysia \\ Email: hapsahsm@uitm.edu.my
}

\begin{abstract}
The aim of the paper is to examine the impact of intellectual capital on firm performance of technology firms listed on the main market of Bursa Malaysia. The study covers a period of seven years from 2013 to 2019 and usable data was drawn from 32 firms, providing 224 observations for the analysis. Intellectual capital is proxy by Modified Value Added Intellectual Coefficient (MVAIC), human capital efficiency (HCE), structural capital efficiency (SCE), relational capital efficiency (RCE) and capital employed efficiency (CEE), while performance is proxy by return on asset (ROA). The empirical findings reveal a positive and significant association between MVAIC and ROA but a mixed relationships between the efficiency of MVAIC components and ROA. Two components, HCE and CEE, are positive and significantly associated with ROA. SCE is significant but negatively associated with ROA. While, RCE is insignificantly associated with ROA. There are some limitations associated with the study. The research outcome is specific to technology sector; therefore, the findings cannot be generalised to other industries. Further, the analysis uses MVAIC model and the model does not cover innovation capital and process capital, thus it may omit other aspects of intellectual capital. Some practical implications from the findings are to achieve higher future profitability, technology firms should not only manage physical capital effectively but also improve employee, internal processes and networking efficiently.

Keywords: Intellectual Capital, Technology Sector, MVAIC Model, ROA.
\end{abstract}




\section{Introduction}

Global transition to knowledge-based economy during the third industrial revolution in 1990s has created a new economic model that account 'knowledge' as factor input in the firm production process in addition to capital and labour (Harris, 2011). Accordingly, the knowledgebased economy has raise the importance of intellectual capital or knowledge assets as the firm's key resources in gaining and sustaining competitive advantage (Martin-de-Castro, DelgadoVerde, Lopez-Saez and Navas-Lopez, 2011) through various value creations that requires human intellects (Lerro, Linzalone, and Schiuma, 2014). The critical role of intellectual capital for the firm in balancing the innovation and exploitation activities is further emphasised in the present fourth industrial revolution era (Mahmood and Mubarik, 2020). Going forward, intellectual capital is the key assets for the firm survival.

Intellectual capital is a broad concept which is often divided into various components and the widely accepted components are human, structural and relational capital (Ting, Ren, Chen and Kweh, 2020). Human capital is described as the abilities, knowledge and experience that when employees leave, they take with them. At the same time, the knowledge that stays within the organisation is known as structural capital. Relational capital is characterised as all resources linked to the company's external relationships (Starovic and Marr, 2003). Intellectual capital is perceived as an intangible, reusable and manageable asset that can be used to build sustainable resources, accessible at the micro-level comprising individuals and organisations and the macrolevel including cities, regions, and countries (Matos, Vairinhos, Selig and Edvinsson, 2019). For both society and organisations, intellectual capital is critical. In the context of an organization, it could be a source of competitive business advantage and stimulating innovation that leads to the generation of wealth. In an atmosphere of constant change, the ability to react effectively to unexpected events and consistently generate value is precisely the aim and province, the function and rationale of intellectual capital. Intellectual capital's unique focus is to assist build businesses that are prepared for strategic surprises and change (Rastogi, 2003).

The literature of intellectual capital has revealed the significance of intellectual capital on firm performance, and it has captured significant attention from scholars over the last three decades. Past studies have covered a wide range of industries and scholars often classify them into the knowledge-intensive sector (e.g. banks, finance, and technology) and capital-intensive sector (e.g. oil and gas, textile). Of the firms in the knowledge-intensive sector, the widely investigated are financial institutions involving banks and finance, but very few studies concentrated on technology firms (Vishnu and Gupta, 2014; Dženopoljac, Janoševic and Bontis, 2016). Generally, prior studies reported consistent empirical findings on the impact of intellectual capital on firm performance involving financial institutions, suggesting the positive association enhances firm performance. However, concerning technology firms, the results were inconclusive.

Based on the literature review undertaken, it is discovered that minimal empirical studies have endeavoured to clarify on intellectual capital and its association with firm performance of technology firms in Malaysia using Modified Value-Added Intellectual Coefficient model (Nimtrakoon, 2015). Thus, the findings of this paper aim to fill that void. The primary objective of the study is to examine the impact of intellectual capital on firm performance of technology firms 
in Malaysia. The specific objectives are to examine the impact of intellectual capital on firm performance using MVAIC model and to investigate the separate effect of human capital efficiency (HCE), structural capital efficiency (SCE), relational capital efficiency (RCE) and capital employed efficiency (CEE) on firm performance.

The paper is structured as follows. Section 2 provides literature review and research hypotheses. Section 3 presents methodology of the study. Section 4 provides analysis and discussion on the findings. Section 5 presents conclusion of the study.

\section{Literature Review and Hypotheses}

In the accounting and finance literature, research has been devoted to intellectual capital disclosure, measurement, and impacts to firm performance (Ashton, 2005; Kamath, 2008; Maditinos et al., 2011; Dumay, Guthrie and Rooney, 2020). This research specifically focuses on intellectual capital impacts to firm performance.

Past studies have covered a wide range of industries and scholars often classify them into the knowledge-intensive sector (e.g. banks, finance, and technology) and capital-intensive sector (e.g. oil and gas, textile). Further, the knowledge-intensive sector tends to invest more in intellectual capital than capital-intensive sector to gain competitive advantage (Vishnu et al., 2014; Nimtrakoon, 2015; Dzenopoljac et al., 2016; Xu and Li, 2019). Of the firms in the knowledge-intensive sector, the widely investigated are financial institutions involving banks and finance, but very few studies concentrated on technology firms (Vishnu et al., 2014; Dženopoljac et al., 2016). Generally, prior studies reported consistent empirical findings on the impact of intellectual capital on firm performance involving financial institutions, suggesting the positive association enhances firm performance. Al-Musali and Ismail (2016) studied the relationship between intellectual capital investment and firm performance of listed commercial banks in Gulf countries, and their study identified a positive association. Irsyahma and Nikmah (2017), drawing from the Indonesian banking sector, reported a positive association between intellectual capital and firm performance, implying banks with a higher degree of intellectual capital efficiency would demonstrate higher performance. Research by Tiwari and Vidyarthi (2018) exhibited a positive correlation between intellectual capital and firm performance in Indian public and private banks, suggesting banks with better intellectual capital efficiency usually have a better performance. A study by Tran and Vo (2018) on Thailand listed banks, Ousama, Hammami and Abdulkarim (2019) on Islamic banks of Gulf countries and Soewarno and Tjahjadi (2020) on Indonesian banks reported similar results, a positive and significant association between intellectual capital and firm performance.

However, concerning technology firms, there is little evidence and the results were inconclusive. Nimtrakoon (2015) conducted an empirical analysis of intellectual capital and firm performance of technology firms across five ASEAN countries and discovered a positive impact of intellectual capital on firm performance. The study suggested that intellectual capital may be an indicator of future firm performance. In contrast to the positive association, Dženopoljac et al. (2016) found no significant links between intellectual capital and firm performance in the technology sector of Serbia. Ting et al. (2020) revealed similar results in an analysis involving the relationship between 
intellectual capital and firm performance of technology firms in Taiwan. The empirical findings reported by Dženopoljac et al. (2016) and Ting et al. (2020) provide insights that stakeholders still perceive tangible assets as superior to intellectual capital in generating wealth for the firms. Closely related to this research is the study of intellectual capital impacts on technology-intensive firms in Malaysia which documented that many firms still depend on psychical capital efficiency compared to other intellectual capital components (Gan and Saleh, 2008). Based on the literature review undertaken, it is discovered that minimal empirical studies have endeavoured to clarify on intellectual capital and its association with firm performance of technology firms in Malaysian using MVAIC model.

In reference to the empirical evidence, the research framework and the corresponding hypotheses are drawn below.

$\mathrm{H} 1$ There is a positive and significant association between MVAIC and Profitability.

$\mathrm{H} 2$ There is a positive association between MVAIC components and Profitability.

a. There is a positive and significant association between HCE and higher Profitability.

b. There is a positive and significant association between SCE and higher Profitability.

c. There is a positive and significant association between RCE and higher Profitability

d. There is a positive and significant association between CEE and higher Profitability.

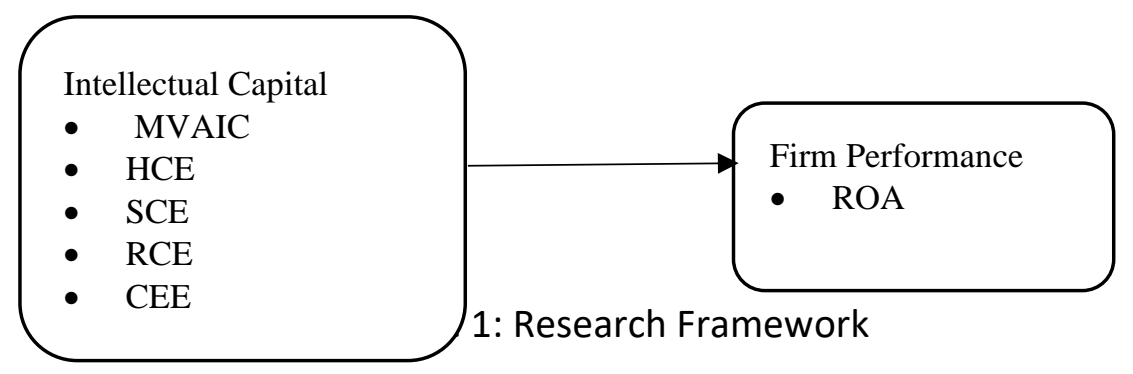

\section{Data and Methodology}

The secondary data used in this empirical study were collected from the published annual reports of technology firms listed in the main board of Bursa Malaysia over the seven-year period from 2013 to 2019. As of 31 August 2020, a total of 40 firms were listed, however usable data was drawn from 32 firms, providing 224 observations for the analysis. MVAIC model was employed to measure intellectual capital efficiency. The following table provides the description of the model. 
INTERNATIONAL JOURNAL OF ACADEMIC RESEARCH ECONOMICS AND MANAGEMENT SCIENCES Vol. 10, No. 1, 2021, E-ISSN: 2226-3624 ㄷ 2021 HRMARS

Table 1: Measurement of Intellectual capital using MVAIC model.

\begin{tabular}{|c|c|c|c|}
\hline $\begin{array}{c}\text { Model } \\
\text { Components }\end{array}$ & Definition & Formula & Explanation of Terms \\
\hline Value Added (VA) & $\begin{array}{l}\text { The value created by } \\
\text { the firm as operating } \\
\text { profit before interest } \\
\text { and tax (EBIT), adding } \\
\text { back non-cash } \\
\text { expenses like } \\
\text { depreciation, } \\
\text { amortisation and } \\
\text { employee costs. }\end{array}$ & $\begin{array}{l}V A=P+E+D+ \\
A\end{array}$ & $\begin{array}{l}P=\text { Operating Profit } \\
E=\text { Employee costs } \\
D=\text { Depreciation } \\
A=\text { Amortisation }\end{array}$ \\
\hline Human Capital (HC) & $\begin{array}{l}\text { The expenses related to } \\
\text { employee } \\
\text { compensation and } \\
\text { development. }\end{array}$ & $\begin{array}{l}\mathrm{HC}=\text { Total } \\
\text { wages and } \\
\text { salary cost }\end{array}$ & $\mathrm{HC}=\mathrm{E}$ \\
\hline HCE & $\begin{array}{l}\text { The contribution made } \\
\text { by every unit of money } \\
\text { invested in } \mathrm{HC} \text { to the } \\
\text { VA. }\end{array}$ & $\mathrm{HCE}=\mathrm{VA} / \mathrm{HC}$ & $\begin{array}{l}\text { HCE = Human Capital } \\
\text { Efficiency } \\
\text { VA = Value Added } \\
\text { HC = Human capital }\end{array}$ \\
\hline $\begin{array}{l}\text { Structural Capital } \\
\text { (SC) }\end{array}$ & $\begin{array}{l}\text { The supportive } \\
\text { infrastructure that } \\
\text { enables } \mathrm{HC} \text { to function. }\end{array}$ & $\mathrm{SC}=\mathrm{VA}-\mathrm{HC}$ & $\begin{array}{l}\text { VA }=\text { Value Added } \\
\mathrm{SC}=\text { Structural Capital }\end{array}$ \\
\hline SCE & $\begin{array}{l}\text { The contribution made } \\
\text { by every unit of money } \\
\text { invested in SC to the } \\
\text { VA. }\end{array}$ & $\mathrm{SCE}=\mathrm{SC} / \mathrm{VA}$ & $\begin{array}{l}\text { SCE }=\text { Structural Capital } \\
\text { Efficiency } \\
\text { VA = Value Added } \\
\text { SC }=\text { Structural capital }\end{array}$ \\
\hline $\begin{array}{l}\text { Relational Capital } \\
\text { (RC) }\end{array}$ & $\begin{array}{l}\text { The expenses related to } \\
\text { selling and distribution } \\
\text { cost or marketing } \\
\text { expenses. }\end{array}$ & $\begin{array}{l}\mathrm{RC}=\text { Total } \\
\text { selling and } \\
\text { distribution cost }\end{array}$ & \\
\hline RCE & $\begin{array}{l}\text { The contribution made } \\
\text { by every unit of money } \\
\text { invested in RC to the } \\
\text { VA. }\end{array}$ & $\mathrm{RCE}=\mathrm{RC} / \mathrm{VA}$ & $\begin{array}{l}\text { SCE }=\text { Relational } \\
\text { Capital Efficiency } \\
\text { VA = Value Added } \\
\text { RC }=\text { Relational capital }\end{array}$ \\
\hline Capital Employed & $\begin{array}{l}\text { Representing capital } \\
\text { expenditure of the } \\
\text { company. }\end{array}$ & $C E=T A-I A$ & $\begin{array}{l}\mathrm{TA}=\text { Total assets } \\
\mathrm{IA}=\text { Intangible assets }\end{array}$ \\
\hline CEE & $\begin{array}{l}\text { The contribution made } \\
\text { by every unit of money } \\
\text { invested in physical } \\
\text { capital to the VA. }\end{array}$ & $\mathrm{CEE}=\mathrm{VA} / \mathrm{CE}$ & $\begin{array}{l}\text { CEE }=\text { Capital } \\
\text { Employed Efficiency } \\
\text { VA = Value Added } \\
\text { CE = Capital Employed }\end{array}$ \\
\hline
\end{tabular}

Source: Adapted from Chowdhury, Rana and Azim (2019) 
The dependent variable, firm performance is viewed from profitability perspective which is proxy by return on asset (ROA). ROA is computed as net income over total assets. It indicates the ability of a firm in utilizing total assets and shows the profitability of a firm. To test the hypotheses of the study the following regression models (1) and (2) have been formulated. In addition to the key human capital variables, the regressors included the $b_{n} Z_{\text {it }}$ which is a set of firm controlled variables documented in empirical evidence including size (SIZE) and leverage (LEV). Firm size is measured as the natural logarithm of total assets and leverage is measured by total debt to total assets. While $\varepsilon_{i t}$ is the standard regression error terms.

Model 1: $\mathrm{ROA}_{i \mathrm{t}}=B_{0}+B_{1} \mathrm{MVAIC}_{\mathrm{it}}+B_{n} \mathrm{Z}_{\mathrm{it}}+\varepsilon_{\mathrm{it}}$

Model 2: $\mathrm{ROA}_{i \mathrm{t}}=b_{0}+b_{1} \mathrm{HCE}_{\mathrm{it}}+b_{2} \mathrm{SCE}_{\mathrm{it}}+b_{3} \mathrm{RCE}_{\mathrm{it}}+b_{4} \mathrm{CEE}_{\mathrm{it}}+b_{n} \mathrm{Z}_{\mathrm{it}}+\varepsilon_{\mathrm{it}}$

\section{Findings and Analysis}

\section{a. Descriptive Analysis}

The descriptive analysis of technology firms is provided in table 2 . The mean value of profitability of technology sector as indicated by ROA which stood at 0.0427 is sound, suggesting that the sample firms were able to generate profit. The value of standard deviation for each of the four components of intellectual capital as presented in Table 2 indicated small deviation from mean value (e.g. mean of HCE 2.6930, Std dev 3.5604). The value of standard deviation tests the consistency of the data. It indicates how far the data from each other is similar or different. As a rule of thumb, the lower the standard deviation value, the higher the consistency is. Meanwhile, the value of standard deviation as presented in Table 2 for CEE across technology sector recorded small deviation from their mean values. It shows a high consistency of the treatment in physical capital across firms in the technology sector.

Most variables are highly skewed (less than -1 or greater than +1 ) as indicated in the table 2 (Bulmer, 1979). Despite the skewness values, these variables are not transformed into a natural logarithm function (a method chosen to mitigate normality problem) due to the data being in percentage. The kurtosis values as presented in table 2 indicated all variables, HCE, SCE, RCE, CEE, MVAIC, ROA, SIZE, except leverage have kurtosis problem where the kurtosis values more than three indicating a leptokurtic distribution characterized by higher and sharper central peak with tails longer and fatter due to the kurtosis problem (Akinlawon, Asiribo and Adebanji, 2010). For leverage, the kurtosis value is three indicating normal distribution. The kurtosis problem in the data may not create an obstacle to produce quality and reliable statistics as this is expected in a research with financial time series. Akinlawon et al. (2010) argued that studies with financial time series often exhibited leptokurtosis value greater than 3. A leptokurtic situation may happen in both, the unconditional distribution and conditional distribution of daily asset returns (Akinlawon et al., 2010). In addition, when the sample size is large that is the number of observation is greater than 30, a variable with statistically significant skewness and kurtosis can be considered as a variable with normal distribution (Tabachnik and Fidell, 2007; Hair, Black, Babin and Anderson, 2010). Since the sample size is large $(n=224)$ normal distribution of data can be considered in this study. 
INTERNATIONAL JOURNAL OF ACADEMIC RESEARCH ECONOMICS AND MANAGEMENT SCIENCES Vol. 10, No. 1, 2021, E-ISSN: 2226-3624 @ 2021 HRMARS

\begin{tabular}{|l|l|c|c|c|c|c|c|}
\hline \multicolumn{2}{|l|}{ Table 2: Descriptive Analysis for Technology Sector } \\
\hline Sector & $\begin{array}{l}\text { Variable } \\
\text { S }\end{array}$ & Mean & Min & Max & Std.Dev. & $\begin{array}{r}\text { Skewnes } \\
\text { s }\end{array}$ & Kurtosis \\
\hline Technology & HCE & 2.6930 & $\begin{array}{r}- \\
3.50938\end{array}$ & 27.8748 & 3.5604 & 4.0984 & 23.8975 \\
\hline & SCE & 0.4622 & -7.1952 & 5.8058 & 0.7995 & -2.3949 & 48.3016 \\
\hline & RCE & 0.0626 & 0.73443 & 1.4853 & 0.1918 & 2.5938 & 19.9029 \\
\hline & CEE & 0.2601 & 0.49849 & 0.5563 & 0.1564 & -0.9504 & 5.6893 \\
\hline & MVAIC & 3.4778 & 6.07903 & 29.0658 & 3.7650 & 3.6129 & 20.9367 \\
\hline & ROA & 0.0427 & -0.7519 & 0.3580 & 0.1416 & -1.7366 & 9.8911 \\
\hline & SIZE & 5.3100 & 0 & 6.2660 & 0.7841 & -4.1327 & 28.7487 \\
\hline & LEV & 0.3013 & 0 & 0.6792 & 0.1440 & 0.4873 & 2.8570 \\
\hline
\end{tabular}

Notes: Number of observation is 224 .

A comparison of MVAIC components as depicted in table 3 below suggest that all the firms in technology sector are generally more efficient in generating value from their human capital rather than structural capital, relational capital and capital employed. HCE is an indicator of value added by the human resources employed by the business, a HCE of 2.693 means for every RM1 invested, the firms create RM2.693 from its human capital. Following, SCE of 0.4622 indicated that for every RM1 invested, the firms create value of RM0.4622 from its structural capital. In terms of RCE, for every RM1 invested, the firms create RM0.0626 from its relational capital. Next, CEE of 0.2601 indicating that for every RM1 worth of investment, the value created from physical capital is RM0.2601. CEE is an indicator of efficiency in generating value from physical capital. It shows that technology firms are efficient in managing both, intellectual capital and physical capital, in creating values.

The percentage (\%) next to the components of intellectual capital indicate the contribution towards MVAIC in technology sector. Of the four components of intellectual capital, HCE stood at $77.43 \%$, followed by SCE at $13.29 \%$ then CEE at $7.48 \%$ and lastly RCE at $1.8 \%$. RCE's contribution towards MVAIC in technology sector is very minimum in comparison to the other three components. It shows as presented in Table 3, HCE has a significant contribution towards MVAIC in the technology sector. As a conclusion, HCE is the main component of MVAIC as it makes a major contribution towards the value of MVAIC. HCE largely determines intellectual capital efficiency in technology sector. These findings supported the findings of Nawaz and Haniffa (2017); Ozkan, Cakan and Kayacan (2017); Tran et al. (2018). With regard to MVAIC, the greater the value of MVAIC indicates a higher efficiency level of the company.

The mean of the four components are presented below in order to evaluate the intellectual capital performance of technology firms using the MVAIC model: 
INTERNATIONAL JOURNAL OF ACADEMIC RESEARCH ECONOMICS AND MANAGEMENT SCIENCES Vol. 10 , No. 1, 2021, E-ISSN: 2226-3624 @ 2021 HRMARS

Table.3: Mean of Intellectual Capital Performance (Sector) using MVAIC
\begin{tabular}{|l|c|c|c|c|c|c|c|c|c|c|}
\hline Sector & $\begin{array}{c}\text { HCE } \\
\text { (a) }\end{array}$ & $\%$ & $\begin{array}{c}\text { SCE } \\
\text { (b) }\end{array}$ & $\%$ & $\begin{array}{c}\text { RCE } \\
\text { (c) }\end{array}$ & $\%$ & $\begin{array}{c}\text { CEE } \\
\text { (d) }\end{array}$ & $\%$ & $\begin{array}{c}\text { MVAIC } \\
(\mathrm{a}+\mathrm{b}+\mathrm{c}+\mathrm{d})\end{array}$ & $\%$ \\
\hline Technology & 2.6930 & 77.43 & 0.4622 & 13.29 & 0.0626 & 1.8 & 0.2601 & 7.48 & 3.4778 & 100 \\
\end{tabular}

\section{b. Pearson Correlation Analysis}

The Pearson correlation analysis of the technology sector is provided in the following table. Table 4 shows that the correlation value indicated significant positive associations between only several pairs of variables. As expected, MVAIC has significant positive correlation with firm's financial performance, ROA. It implies that firms with greater intellectual capital efficiency have higher financial performance. Specifically, MVAIC is significantly and positively related to ROA ( $r=0.4031, p<0.0001)$, indicating strong relationship between value efficiency and financial performance. Regarding the components of MVAIC, HCE, SCE and CEE exhibited significant positive correlations with ROA, except RCE. CEE $(r=0.6811, p<0.0001)$ have the strongest correlation with ROA. HCE $(r=0.3878, p<0.0001)$ and SCE $(r=0.0393, p<0.0001)$ also implies significant positive correlations, but weakly correlated with ROA. Meanwhile, RCE have no correlation with ROA. It is noted that MVAIC has significant positive relationships with the components of intellectual capital except RCE. MVAIC has the strongest association with HCE $(r=0.9826, p<0.0001)$, followed by its relationship with SCE $(r=0.3353, p<0.0001)$ but weakly correlated with physical capital $(r=0.1236, p<0.0001)$. One of the control variables, size, demonstrated weak correlation with profitability, ROA at correlation values of 0.2079 $(p<0.0001)$. Size and leverage recorded significant positive correlation among themselves, but it is a weak association ( $r=0.2903, p<0.0001)$. The pairwise correlation between MVAIC and HCE is very strong suggesting multicollinearity problem (Gujarati, Porter and Gunasekar, 2017). Therefore, to mitigate the problem the two explanatory variables are separated into model 1 and model 2 in the study. 
INTERNATIONAL JOURNAL OF ACADEMIC RESEARCH ECONOMICS AND MANAGEMENT SCIENCES Vol. 10, No. 1, 2021, E-ISSN: 2226-3624 @ 2021 HRMARS

\begin{tabular}{|c|c|c|c|c|c|c|c|c|c|}
\hline Sector & $\begin{array}{c}\text { Variab } \\
\text { les }\end{array}$ & HCE & SCE & RCE & CEE & MVAIC & ROA & SIZE & LEV \\
\hline \multirow[t]{8}{*}{$\begin{array}{l}\text { Technol } \\
\text { ogy }\end{array}$} & HCE & 1.0000 & & & & & & & \\
\hline & SCE & $\begin{array}{l}0.1629 \\
* *\end{array}$ & 1.0000 & & & & & & \\
\hline & RCE & -0.0502 & $\begin{array}{l}0.5147 \\
* * *\end{array}$ & $\begin{array}{l}1.00 \\
00\end{array}$ & & & & & \\
\hline & CEE & $\begin{array}{l}0.1176 \\
*\end{array}$ & $\begin{array}{l}- \\
0.1188\end{array}$ & $\begin{array}{l}- \\
0.07 \\
66\end{array}$ & 1.0000 & & & & \\
\hline & $\begin{array}{l}\text { MVAI } \\
\text { C }\end{array}$ & $\begin{array}{l}0.9826 \\
* * *\end{array}$ & $\begin{array}{l}0.3353 \\
* * *\end{array}$ & $\begin{array}{l}- \\
0.10 \\
91\end{array}$ & $\begin{array}{l}0.1236 \\
*\end{array}$ & 1.0000 & & & \\
\hline & ROA & $\begin{array}{l}0.3878 \\
* * *\end{array}$ & 0.0393 & $\begin{array}{l}- \\
0.00 \\
50\end{array}$ & $\begin{array}{l}0.6811 \\
* * *\end{array}$ & $\begin{array}{l}0.4031 \\
* * *\end{array}$ & 1.0000 & & \\
\hline & SIZE & $\begin{array}{l}0.2344 \\
* * *\end{array}$ & $\begin{array}{l}0.1121 \\
*\end{array}$ & $\begin{array}{l}0.02 \\
85\end{array}$ & $\begin{array}{l}0.2509 \\
* * *\end{array}$ & $\begin{array}{l}0.2573 \\
* * *\end{array}$ & $\begin{array}{l}0.2079 \\
* *\end{array}$ & 1.0000 & \\
\hline & LEV & $\begin{array}{l}- \\
0.1505 \\
* *\end{array}$ & -0.0972 & $\begin{array}{l}0.11 \\
79 *\end{array}$ & $\begin{array}{l}- \\
0.1423 \\
* *\end{array}$ & $\begin{array}{l}- \\
0.1629 \\
* *\end{array}$ & $\begin{array}{l}- \\
0.2469 \\
* * *\end{array}$ & $\begin{array}{l}0.2903 \\
* * *\end{array}$ & $\begin{array}{l}1.00 \\
00\end{array}$ \\
\hline
\end{tabular}

Notes: Number of observation is 224 . The $\operatorname{sign} * * *, * *, *$ denotes the correlation significant level at $0.01,0.05$ and 0.1 respectively.

\section{c. Regression Analysis}

Table 5 presents the results of the two regression models in this study, applying the control variables of firm size and leverage. In model 1 , the value of $R^{2}$ of 0.2107 indicated that 21.07 percent of possible variations in ROA is explained by MVAIC and the reliability is examined through its F-value of $68.61(p<0.0000)$ which is found to be statistically significant. MVAIC is positively and significantly associated with ROA with the coefficients of 0.0170 . The result implies that as MVAIC increases by RM1, ROA increases by RM0.017. The findings support $\mathrm{H} 1$, confirming that firms with greater MVAIC tend to have higher ROA. For model 2, the MVAIC components explain 54 per cent of the variations in ROA with an adjusted $R^{2}$ of 0.5441 having control variables of firm size and leverage in the analysis. The model with F-value of $69.89(p<0.0000)$ is statistically significant for prediction. The study reveals a mixed relationship between the efficiency of MVAIC components and ROA of technology firms for the seven-year study period, 2013-2019. Two components of MVAIC, HCE and CEE, are found to be positively and significantly associated with ROA with the coefficients of 0.0086 and 0.6284 respectively. The findings imply that as HCE and CEE increases by RM1, ROA increases by RM0.009 and RM0.63 respectively. Other components 
of MVAIC, SCE, is significant but negatively associated with ROA. On the other hand, RCE is insignificantly associated with ROA. Of the four components of MVAIC, the efficiency level of CEE (0.63) indicated a decisive role in ensuring higher profitability and reaffirming the premature stage of intellectual capital utilisation in technology sector of a developing country. The findings support $\mathrm{H} 2$ (a) and (d), confirming that firms with greater HCE and CEE, but not with SCE and RCE, tend to have higher ROA.

The two control variables in the study, firm size and leverage, document different results. Firm size in both models are insignificantly associated with ROA indicating that firm size, big or small, does not influence profitability. For leverage, both models exhibit similar pattern of relationship that is it affects ROA negatively. The higher the profit level, the lower the level of leverage indicating pattern of financing in line with pecking-order theory and empirical evidence.

These results are broadly in line with prior research findings (e.g. Nimtrakoon, 2015; Al-Musali et al., 2016; Ozkan et al., 2017; Ousama et al., 2019; Xu et al., 2019), confirming firms with greater level of intellectual capital will exhibit higher profitability. Regarding the four components of MVAIC, CEE and HCE, are the most influential value drivers according to their association with ROA. The findings suggest that physical capital (proxy by CEE) is still relevant in generating firms' profitability and has long been associated with value creation process (Nimtrakoon, 2015). In addition, the findings also imply that human capital, has been acknowledged as an effective source of wealth creation. It could be attributed to the fact that human capital is vested in employees rather than the firm (Edvinsson, 1997; Nimtrakoon, 2015). Among MVAIC components, SCE and RCE seem to be the least influential value drivers. 
INTERNATIONAL JOURNAL OF ACADEMIC RESEARCH ECONOMICS AND MANAGEMENT SCIENCES Vol. 10, No. 1, 2021, E-ISSN: 2226-3624 @ 2021 HRMARS

Table 5: Regression Results for Model 1 and 2

\begin{tabular}{|l|c|c|}
\hline Model & 1 & 2 \\
\hline Variables & ROA & ROA \\
\hline Cons & -0.0313 & -0.0474 \\
t-value & $(-0.58)$ & $(-1.35)$ \\
\hline MVAIC & $\mathbf{0 . 0 1 7 0 ^ { * * * }}$ & $\mathrm{NA}$ \\
$\mathrm{t}$-value & $(\mathbf{6 . 9 6 )}$ & $\mathbf{0 . 0 0 8 6 ^ { * * * }}$ \\
\hline HCE & & $\mathbf{( 4 . 3 1 )}$ \\
t-value & & $-0.0099^{* * *}$ \\
\hline SCE & & $(4.31)$ \\
t-value & & -0.0179 \\
\hline RCE & & $(-0.46)$ \\
t-value & & $\mathbf{0 . 6 2 8 4 * *}$ \\
\hline CEE & & $(\mathbf{1 5 . 0 7 )}$ \\
t-value & & -0.0073 \\
\hline Size & 0.0131 & $(-0.98)$ \\
t-value & $(1.20)$ & $-0.1721^{* * *}$ \\
\hline Lev & $-0.1815^{* *}$ & $(-3.34)$ \\
t-value & $(-2.56)$ & 0.5441 \\
\hline R-Sq & 0.2107 & $69.89^{* * *}$ \\
F-stat & $\mathrm{N} / \mathrm{A}$ & $(0.0000)$ \\
Sig F-stat & $\mathrm{N} / \mathrm{A}$ & $\mathrm{N} / \mathrm{A}$ \\
Wald Chi-Sq & $68.61^{* * *}$ & $\mathrm{~N} / \mathrm{A}$ \\
p-value & $(0.0000)$ & \\
\hline
\end{tabular}

Notes: Notes: Number of observation is 224 . The sign $* * *, * *, *$ denotes the correlation significant level at $0.01,0.05$ and 0.1 respectively. The figures in the parentheses are the tstatistics.

\section{Conclusion}

This study is one of few studies focusing on intellectual capital utilisation in Malaysia technology sector. The empirical findings reveal a positive and significant association between MVAIC and profitability, suggesting that intellectual capital affects profitability of technology firms. However, a mixed relationships between the efficiency of MVAIC components and profitability are noted. A separate analysis into the components of MVAIC revealed that two components, HCE and CEE, are found to be positive and significantly associated with ROA. SCE is significant but negatively associated with ROA. While, RCE is insignificantly associated with ROA. Even though, both HCE and CEE are positive and significantly correlated with ROA, but CEE recorded higher efficiency level. As Malaysia is still a developing country and the technology sector is still developing, the findings of the study suggest that profitability is primarily driven by CEE which is in line with the study of Chowdhury, Rana, Akter and Hoque (2018); Ozkan et al. (2017). Therefore, the conclusion that can be drawn from the findings of the study is that both, physical capital and intellectual capital affect profitability, but physical capital is the primary determinant of profitability and the utilisation of intellectual capital is still at a low level. 
The findings of the current study may offer several practical contributions. First, managers of technology firms should increase their firms' recognition of intellectual capital utilization in enhancing their profitability through gaining a better understanding of intellectual capital and put greater effort on its management. This is especially so as Malaysia is currently operating in knowledge-based economy, where firms' reliance on intellectual capital as a source of competitive advantage is greatly enhanced. Second, regarding the low-HCE, firms may revise their employees' financial and non-financial rewards schemes and employee-related programs such as training to enhance employee capability, attitude and satisfaction. Third, to enhance structural capital, the firm may consider re-designing and creating a conducive organizational culture, management control system and a strong information technology system to support internal processes and operations. Fourth, to strengthen relational capital, the firms may establish networking with valuable partners such as suppliers and customers.

There are some limitations associated with the study. The current research is limited to listed technology firms in the main board of Bursa Malaysia, therefore, the findings cannot be generalised to other industries. Further, the analysis uses MVAIC models and the model does not cover innovation capital and process capital, thus it may omit other aspects of intellectual capital. Therefore, future research may consider investigating the impact of intellectual capital on profitability using other sector as a research setting. To examine other aspect of intellectual capital by adopting different measurement model such as Integrated Intellectual Capital Model.

\section{References}

Akinlawon, O. J., Asiribo, O. E., \& Adebanji, A. O. (2010). Optimum conditional distribution for estimating the volatility of stock indices. College of Natural Sciences Proceedings, 51-59.

Al-Musali, M. A., \& Ismail, K. N. I. K. (2016). Cross-country comparison of intellectual capital performance and its impact on financial performance of commercial banks in GCC countries. International Journal of Islamic and Middle Eastern Finance and Management, 9(4), 512-531.

Ashton, R. H. (2005). Intellectual capital and value creation: a review. Journal of Accounting Literature, 24, 53-134.

Bulmer, M. G. (1979). Principles of Statistics (3rd ed.). Dover Publications.

Chowdhury, L. A. M., Rana, T., Akter, M., \& Hoque, M. (2018). Impact of intellectual capital on financial performance: Evidence from the Bangladeshi textile sector. Journal of Accounting \& Organizational Change, 14(4), 429-454.

Chowdhury, L. A. M., Rana, T., \& Azim, M. I. (2019). Intellectual capital efficiency and organisational performance. Journal of Intellectual Capital, 20(6), 784-806.

Dumay, J., Guthrie, J., \& Rooney, J. (2020). Being critical about intellectual capital accounting in 2020: An overview. Critical Perspectives on Accounting, 70, 1-9.

Dženopoljac, V., Janoševic, S., \& Bontis, N. (2016). Intellectual capital and financial performance in the Serbian ICT sector. Journal of Intellectual Capital, 17(2), 373-396.

Edvinsson, L. (1997). Developing intellectual capital at Skandia. Long range planning, 30(3), 366373. 
Gan, K., \& Saleh, Z. (2008). Intellectual capital and corporate performance of technologyintensive companies: Malaysia evidence. Asian Journal of Business and Accounting, 1(1), 113-130.

Gujarati, D., Porter, D., \& Gunasekar, S. (2017). Basic Econometrics (5th ed.). Mcgraw.

Hair, J. F., Black, W. C., Babin, B. J., \& Anderson, R. E. (2010). Multivariate Data Analysis (7th ed.). Pearson.

Harris, R. G. (2001). The knowledge-based economy: Intellectual origins and new economic perspectives. International Journal of Management Reviews, 3(1), 21-40.

Irsyahma, A., \& Nikmah, N. (2017). Intellectual capital, firm value, and financial performance. AFEBI Accounting Review, 1(01), 29-43.

Kamath, B. (2008). Intellectual capital disclosure in India: Content analysis of "TecK" firms. Journal of Human Resource Costing \& Accounting, 12(3), 213-224.

Lerro, A., Linzalone, R., \& Schiuma, G. (2014). Managing intellectual capital dimensions for organizational value creation. Journal of Intellectual Capital, 15(3), 350-361.

Maditinos, D., Chatzoudes, D., Tsairidis, C., \& Theriou, G. (2011). The impact of intellectual capital on firms' market value and financial performance. Journal of Intellectual Capital, 12(1), 132-151.

Mahmood, T., \& Mubarik, M. S. (2020). Balancing innovation and exploitation in the fourth industrial revolution: Role of intellectual capital and technology absorptive capacity. Technological Forecasting and Social Change, 160, 120248.

Martín-de-Castro, G., Delgado-Verde, M., López-Sáez, P., \& Navas-López, J. E. (2011). Towards "an intellectual capital-based view of the firm": Origins and nature. Journal of Business Ethics, 98(4), 649-662.

Matos, F., Vairinhos, V., Selig, P. M., \& Edvinsson, L. (2019). Intellectual Capital Management as a Driver of Sustainability. Springer.

Nawaz, T., \& Haniffa, R. (2017). Determinants of financial performance of Islamic banks: An intellectual capital perspective. Journal of Islamic Accounting and Business Research, 8(2), 130-142.

Nimtrakoon, S. (2015). The relationship between intellectual capital, firms' market value and financial performance. Journal of Intellectual Capital, 16(3), 587-618.

Ousama, A. A., Hammami, H., \& Abdulkarim, M. (2019). The association between intellectual capital and financial performance in the Islamic banking sector. International Journal of Islamic and Middle Eastern Finance and Management, 13(1), 75-93.

Ozkan, N., Cakan, S., \& Kayacan, M. (2017). Intellectual capital and financial performance: A study of the Turkish Banking Sector. Borsa Istanbul Review, 17(3), 190-198.

Petty, R., \& Guthrie, J. (2000). Intellectual capital literature review: Measurement, reporting and management. Journal of Intellectual Capital, 1(2), 155-176.

Rastogi, P. N. (2003). The nature and role of IC: Rethinking the process of value creation and sustained enterprise growth. Journal of Intellectual Capital, 4(2), 227-248.

Soewarno, N., \& Tjahjadi, B. (2020). Measures that matter: An empirical investigation of intellectual capital and financial performance of banking firms in Indonesia. Journal of Intellectual Capital, 21(6), 1085-1106.

Starovic, D., \& Marr, B. (2003). Understanding corporate value: managing and reporting intellectual capital. CIMA. 
Tabachnick, B. G., \& Fidell, L. S. (2012). Using Multivariate Statistics (6th ed.). Pearson.

Ting, I. W. K., \& Lean, H. H. (2009). Intellectual capital performance of financial institutions in Malaysia. Journal of Intellectual capital, 10(4), 588-599.

Ting, I. W. K., Ren, C., Chen, F. C., \& Kweh, Q. L. (2020). Interpreting the dynamic performance effect of intellectual capital through a value-added-based perspective. Journal of Intellectual Capital, 21(3), 381-401.

Tiwari, R., \& Vidyarthi, H. (2018). Intellectual capital and corporate performance: A case of Indian banks. Journal of Accounting in Emerging Economies, 8(1), 84-105.

Tran, N. P., \& Vo, D. H. (2020). Do banks accumulate a higher level of intellectual capital? Evidencerom an emerging market. Journal of Intellectual Capital.

Vishnu, S., \& Gupta, V. K. (2014). Intellectual capital and performance of pharmaceutical firms in India. Journal of Intellectual Capital, 15(1), 83-99.

Xu, J., \& Li, J. (2019). The impact of intellectual capital on SMEs' performance in China. Journal of Intellectual Capital, 20(4), 488-509. 